\title{
RADIOCARBON DATING IN THE VERNADSKY INSTITUTE V*
}

\author{
A. P. VINOGRADOV, A. L. DEVIRTS, E. I. DOBKINA, \\ and N. G. MARKOVA
}

V. I. Vernadsky Institute of Geochemistry and Analytical Chemistry, Academy of Sciences, USSR, Moscow

\section{Mo-422. Mende village, Hungary}

$28,900 \pm 600$

Charcoal from layer of buried soil from old brick works in Mende, Hungary $\left(47^{\circ} 30^{\prime} \mathrm{N}\right.$ Lat, $19^{\circ} 30^{\prime} \mathrm{E}$ Long) [unconfirmed, D.B.S.]. Deposits are humic loess loams, containing bits of charcoal. Sample at depth ca. $6.5 \mathrm{~m}$. This cross section is one of classical loess excavations in Hungary. Sample coll. 1964, by M. Pechi [Pecs] and D. Khan [Hahn].

\section{Mo-105. Bayya-de-F'yer, Romania}

$>29,000$

Bone of bear from campsite Bayya-de-F'yer [(?) Baia de Fier: ca. $45^{\circ} \mathrm{N}$ Lat, $23^{\circ} \mathrm{E}$ Long] in region of Kraynova [(?) Craiova] in W Romania. Campsite, discovered 1951 by K. S. Nikolescu-Plopshor, contains bones of primitive man and animals with quartzite implements. Sample subm. by N. Khaas [Haas]. Comment: age determined from organic fraction of bone.

Mo-423. Starun' village, L'vov Oblast, Ukrainian SSR $>\mathbf{3 3 , 0 0 0}$

Remains of carcass of woolly rhinoceros (Rhinoceros antiquus) from region of Starun' village [unlocated], L'vov Oblast $\left[46^{\circ} 50^{\prime} \mathrm{N}\right.$ Lat, $24^{\circ}$ $00^{\prime}$ E Long], Ukrainian SSR. Inferred age: last glacial epoch. Subm. [n.d.] by K. K. Markov.

\section{Mo-417. Vulkaneshty II site, Moldavian SSR}

$5810 \pm 150$

Fragment of charred wooden block from shore of Kagul R., Vul-

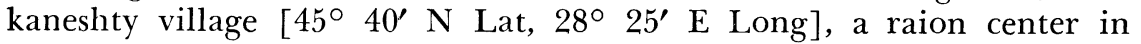
Moldavian SSR. Sample from foundation of dwelling at campsite Vulkaneshty II, belonging to Gumel'nitsa culture distributed along lower Danube in 4th to 3rd millennia B.c. (Gimbutas, 1956). Excavations conducted 1964 by archaeological expedition of Inst. of Archaeol., Acad. of Sci., USSR and Inst. of History, Acad. of Sci., Moldavian SSR. Subm. by T. S. Passek. Comment (D.B.S.): Gumel'nitsa settlements were recently discovered in USSR. The type site is in Romania.

\footnotetext{
Mo-202. Purmalyay I, Lithuanian SSR (revised) $>\mathbf{3 5 , 0 0 0}$

Peat from Purmalyay I settlement, Klaipeda region $\left[55^{\circ} 40^{\prime} \mathrm{N}\right.$ Lat, $21^{\circ} 10^{\prime}$ E Long], Lithuanian SSR, at depth $20 \mathrm{~m}$, overlain by sand with

* Published as, "The determination of absolute age according to $\mathrm{C}^{14}$. Report No. 5." 1966, Geokhimiya, no. 10, p. 1147-1159. Submitted as part of Radiocarbon Dates from Soviet Laboratories, 1 January 1962-1 January 1966. See p. 417, this issue.

** Information in brackets interpolated by translator (E.M.S.) and commentator (D.B.S.).
} 
admixture of organic substances (thickness, ca. $4 \mathrm{~m}$ ) covered by $6 \mathrm{~m}$ stratum of loam containing boulders. Sand with admixture of organic substances also underlies peat. Coll. 1960, and subm. by V. K. Gudelis, Geol. and Geog. Inst., Acad. of Sci., Lithuanian SSR. Inferred age: interstadial, evidently pertaining to last Glaciation.

\section{Venta River series}

Mo-224. Venta River, Latvian SSR

$7110 \pm 170$

[5160 B.c.]

Peat from left bank of Venta R. [5 $57^{\circ} 15^{\prime} \mathrm{N}$ Lat, $21^{\circ} 35^{\prime} \mathrm{E}$ Long] at Varve, $10 \mathrm{~km} \mathrm{~S}$ of Ventsplis, Latvian SSR. Venta R. in this area cuts through Littorina lagoons and older deposits. Samples Mo-224 and 225 coll. 1960 by E. F. Grinbergs. From stratum of bottom [nizhniy] woody peat, $0.27 \mathrm{~m}$ thick and from lower part of superimposed stratum of sapropel-type sediments $0.4 \mathrm{~m}$ thick containing streaks of sand and freshwater mollusc shells. Upper part of cross section holds sandy-pebbly shoreline deposits. Absolute height of crown of exposure is $7.5 \mathrm{~m}$; that of foot of peat stratum is $4.4 \mathrm{~m}$. Peat is overlain by thinly-grained sands, extending under water level of Venta R. Inferred age: beginning of Atlantic phase of Holocene.

\section{Mo-225. Venta River, Latvian SSR}

$8970 \pm 180$

Sandy sapropel from left bank of Venta $R$ at city limits of Vent

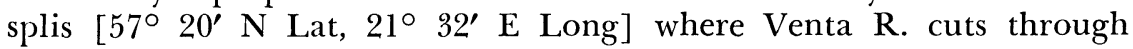
estuary portion of lagoon of Littorina Sea. Absolute height of crown of exposure is $4 \mathrm{~m}$. Fine-grained sand $2.5 \mathrm{~m}$ thick, and sandy sapropel with shells of fresh-water molluscs $0.3 \mathrm{~m}$ thick overlie dusty, blue-gray clays $0.6 \mathrm{~m}$ thick. According to pollen and diatom data, clays were accumulated during transgression of Ancylus Lake; sapropels during regression of lake; and sands during transgression of Littorina Sea. Inferred age: end of Boreal or beginning of Atlantic phase of Holocene.

Mo-375. Karukyula, Estonian SSR

Peat from bog in stratigraphic section at Karukyula $\left[\begin{array}{cc}58^{\circ} & 04^{\prime} \\ \mathrm{N}\end{array}\right.$ Lat, $25^{\circ} 00^{\prime} \mathrm{E}$ Long], on plain formed by basic moraine, $7 \mathrm{~km} \mathrm{~S}$ of Kilingi-Nymme, Pyarnu [Pärnu] Raion, Estonian SSR. Cross section reveals: soil horizon; alluvium with gravel and pebbles (moraine); sand, containing peat and peat with lenses of sand; layer of woody, woodyEquisetum and Equisetum peats; clayey sapropel; aleurites and mediumgrained sand. Sample from woody peat at depth 1.49 to $1.64 \mathrm{~m}$. Inferred age from pollen data: upper climatic optimum of Mikulino [Eem] Interglacial (Orviku and Pirrus, 1965). Coll. 1963 by R. O. Pirrus, Acad. of Sci., Estonian SSR.

Mo-223. Keila-Ioa, Estonian SSR

$7180 \pm 270$ [5230 B.c.]

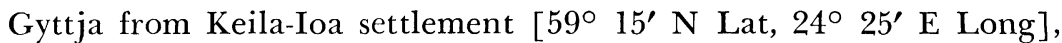
$20 \mathrm{~km} \mathrm{SW}$ of Tallin. Sample is synchronous with formation of peat lens 
20 to $34 \mathrm{~cm}$ thick, underlain by thin stratum of sand (up to $4 \mathrm{~cm}$ ), and carbonaceous bedrock. Peat is $3 \mathrm{~m}$ below high water mark of old shoreline, $23 \mathrm{~m}$ above [present] sea level, and synchronous with shoreline of First Littorina Transgression. Age could correspond to beginning of Atlantic phase of Holocene. Coll. 1960 by Kh. Ya. Kessel.

\section{Mo-222. Saaremaa Island, Estonian SSR}

$8400 \pm 190$

Woody peat and gyttja from Saaremaa Island [ca. $58^{\circ} 30^{\prime} \mathrm{N}$ Lat, $22^{\circ} 30^{\prime}$ E Long], Estonian SSR. Solid mass ca. $20 \mathrm{~cm}$ long from buried peat deposit underlain with sand at $4 \mathrm{~m}$ above surface of carbonaceous bedrock, and $2.5 \mathrm{~m}$ beneath high water mark of ancient shoreline, 17 $\mathrm{m}$ above sea level. Peat deposit is synchronous with shoreline of 2nd Littorina Transgression; inferred age pre-dates this Transgression. Coll. 1960 by Kh. Ya. Kessel.

\section{Sooniste Peat Bog series}

Peat deposit of Sooniste (Eliste) [ca. 59 $35^{\prime} \mathrm{N}$ Lat, $24^{\circ} 45^{\prime} \mathrm{E}$ Long], near Tallin, Estonian SSR. Bog is of upper [recent] type from which peat is currently extracted. After thorough cleaning, samples were taken from pit in 1962 by M. I. Neustadt, Geog. Inst., Acad. of Sci., USSR and R. P. Myannil' (at suggestion of K. K. Orviku). (Cf. Neustadt, 1965, p. 124-29. $[$ D.B.S.])

Mo-363.

$1160 \pm 100$ [A.D. 790]

Fuscum peat, sphagnous, depth 0.32 to $0.38 \mathrm{~m}$. Decomposed, $5 \%$. Inferred age: Sub-Atlantic.

Mo-365.

$2450 \pm 120$

[500 B.c.]

Pine peat with carbonaceous layer, depth, 1.35 to $1.40 \mathrm{~m}$, Boundary Horizon (Cf. Neustadt, 1965, p. 116-24).

Mo-366.

$4630 \pm 200$

Reed peat, depth, 1.90 to $1.95 \mathrm{~m}$. Decomposed, $20 \%$. Inferred age: end of Atlantic.

Mo-367.

$5960 \pm 150$

[4010 B.c. ]

Wood and reed peat, depth, 2.70 to $2.75 \mathrm{~m}$. Decomposed, $25 \%$. Inferred age: Atlantic.

Mo-368.

$9280 \pm 200$

[7330 B.c.]

Wood peat, depth, 3.57 to $3.62 \mathrm{~m}$ (base of peat body). Decomposed, $50 \%$. Inferred age: Boreal.

Mo-369.

$2860 \pm 180$

Wood from stump at Boundary Horizon, depth $1.4 \mathrm{~m}$. Inferred age: 4000 to $4500 \mathrm{yr}$. 


\section{Chyornaya River series}

\section{Mo-216. Chyornaya River, Leningrad Oblast \\ $[5190$ B.C. $]$}

Peat from buried deposit on left bank of Chyornaya R. [60 $60^{\circ} 12^{\prime}$

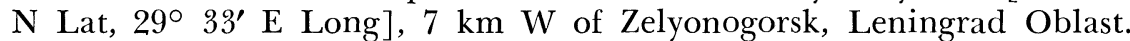
Peat stratum, with aggregate thickness $22 \mathrm{~cm}$, is buried under sandypebbly deposits of shoreline [beregovoy val] with absolute elev. up to $16 \mathrm{~m}$; underlain by compact dark-gray gyttja. Sample from upper part of peat stratum, $8 \mathrm{~cm}$ thick, at depth $4 \mathrm{~m}$ from crown of exposure, $6 \mathrm{~m}$ above water level of Chyornaya R. Inferred age: beginning or middle of Atlantic phase of Holocene. Coll. 1960 by L. R. Serebryannyy, Geog. Inst., Acad. of Sci., USSR.

\section{Mo-217. Chyornaya River, Leningrad Oblast [5290 в.c.]}

Wood from same cross section as Mo-216, $4.4 \mathrm{~m}$ from crown [of exposure], $5.6 \mathrm{~m}$ above water level of Chyornaya R. Sample from upper part of compact dark-gray gyttja ca. $2 \mathrm{~m}$ thick. Inferred age: beginning of Atlantic phase of Holocene.

Kovashi River series

\section{Mo-218. Kovashi River, Leningrad Oblast}

$7810+170$

Peat from right bank of Kovashi R. [ca. $59^{\circ} 55^{\prime} \mathrm{N}$ Lat, $29^{\circ} 15^{\prime} \mathrm{E}$ Long] at Sosnovyy Bor, Leningrad Oblast. Black, strongly-compacted peat $0.4 \mathrm{~m}$ thick is overlain by layer of sand with loamy streaks, and overlies sandy stratum. Sample at depth $1.8 \mathrm{~m}$ from crown of exposure and 0.7 $\mathrm{m}$ above water level of Kovashi R. Inferred age: beginning of Atlantic phase of Holocene. Samples Mo-218 and 220 coll. 1960 by L. R. Serebryannyy.

\section{Mo-220. Kovashi River, Leningrad Oblast}

$7720 \pm 180$ [5770 B.c.]

Wood peat from right bank of Kovashi R., E of highway bridge at Kalishche $\left[59^{\circ} 53^{\prime} \mathrm{N}\right.$ Lat, $29^{\circ} 08^{\prime} \mathrm{E}$ Long], Leningrad Oblast. Sample black, very compact, and saturated with plant remains; coll. at depth 8.2 $\mathrm{m}$ from crown of exposure, $1.8 \mathrm{~m}$ above water level of Kovashi R.; overlain by layer of sand with streaks of loam; overlies sands. Inferred age: beginning of Atlantic phase of Holocene.

\section{Shuvalovo Peat Bog series}

Peat from Shuvalovo bog $\left[60^{\circ} 00^{\prime} \mathrm{N}\right.$ Lat, $30^{\circ} 20^{\prime} \mathrm{E}$ Long], on outskirts of Leningrad. Samples are from buried peat layer, $10 \mathrm{~cm}$ thick, in $\mathrm{W}$ part of bog near Shuvalovo Peat Establishment settlement. Samples Mo-358, 359 coll. 1963 by N. A. Khotinskiy, Geog. Inst., Acad. of Sci., USSR. (Cf. Mo-319-325, Vernadsky Inst. I-IV, 1966). 
Mo-358. Shuvalovo Peat Bog, Leningrad Oblast [1980 B.c.]

Peat from depth 0.10 to $0.15 \mathrm{~m}$. Stratigraphic position suggests layer older than Shuvalovo Bog, lower horizons of which were formed ca. 9000 yr ago.

\section{Mo-359. Shuvalovo Peat Bog, Leningrad Oblast [90 B.c.]}

Peat from depth 0.15 to $0.20 \mathrm{~m}$. Comment: assumption concerning relationship of buried peat deposit with initial deposition of Shuvalovo bog is not confirmed.

\section{Mo-374. Lovat' River, Pskov Oblast}

$12,430 \pm 400$

Plant remains from right bank of Lovat' R. [56 $56^{\circ} 15^{\prime} \mathrm{N}$ Lat, $30^{\circ} 25^{\prime}$

E Long], at Ryzhakovo village, $7 \mathrm{~km} \mathrm{~S}$ of Velikiye Luki, Pskov Oblast. [Site located on $\mathrm{W}$ margin of glacial lake bordering Latgalian moraine (see map opp. p. 28, Zarrina, 1966).] Excavation exposed sandy deposits with inclusion of gravel and layers of silty sand and aleurites, interlayered with small- and coarse-grained sand and subsequently sandy clays. Total depth of excavation is $10 \mathrm{~m}$. Sample taken at depth $4.7 \mathrm{~m}$. Conjectured age is not more than 16,000 yr. Pollen diagram, by R. V. Fedorova, shows that time of sediment accumulation was characterized by flora with Arctic elements. Research was conducted to determine time of glacial recession from Valday in its SW part. Coll. 1963 by N. S. Chebotareva.

\section{Vologda Oblast}

\section{Mo-376. Pudyozhka River, Vologda Oblast}

$2870 \pm 180$

Plant remains from cross section of flood plain on left bank of Pudyozhka R. [59 $20^{\prime} \mathrm{N}$ Lat, $39^{\circ} 40^{\prime} \mathrm{E}$ Long] (right-hand tributary of Vologda R.), in basin of Sukhona R., $10 \mathrm{~km}$ NNW of Vologda. Sample from sand which forms terrace at depth 1.15 to $1.45 \mathrm{~m}$, from stratum of gray and peaty sand. Coll. 1963 by N. S. Chebotareva and V. B. Sokolova.

\section{Mo-377. Vologda River, Vologda Oblast}

$10,860 \pm 320$

Plant remains from cross section of I terrace above flood plain on right bank of Vologda R. [59 $19^{\circ} 18^{\prime} \mathrm{N}$ Lat, $39^{\circ} 41^{\prime} \mathrm{E}$ Long], at Marfino village, $14 \mathrm{~km} \mathrm{NW}$ of Vologda. Coll. 1963 by N. S. Chebotareva and V. B. Sokolova, at depth $4.7 \mathrm{~m}$ from upper part of stratum, which forms base of cross section, consisting of bluish-gray loams and alluvia with plant remains.

\section{Mo-379. Sodima River, Vologda Oblast}

$10,000 \pm 310$

Peat from cross section of Vologda Basin exposed by Sodima R., tributary of Vologda R. Sample coll. 1963 by N. S. Chebotareva and 
V. B. Sokolova from left bank, on SW edge of Vologda $\left[59^{\circ} 15^{\prime} \mathrm{N}\right.$ Lat, $39^{\circ} 55^{\prime}$ E Long], at depth $1.2 \mathrm{~m}$. Layers of peat several $\mathrm{cm}$ thick occur on riverbank cliff in layer of gray loam. Accumulation of sediments could have occurred during interstadial of Valday [Würm] Glaciation. Age [of cross section] according to pollen data, is not clear.

\section{Mo-381. Toshnya River, Vologda Oblast}

Wood and plant remains from cross section of flood plain, left bank of Toshnya R. (basin of Sukhona R.), at Runovo [59 $19^{\circ}$ N Lat, $39^{\circ} 40^{\prime} \mathrm{E}$ Long], $18 \mathrm{~km}$ WSW of Vologda. Sample coll. 1963 by N. S. Chebotareva and V. B. Sokolova at depth $4.1 \mathrm{~m}$ in layer of dark-gray clay and thin layers of light yellow, fine-grained sand from 3rd and most extensive terrace of Toshnya $R$. valley.

\section{Mo-401. Ema River, Vologda Oblast}

Plant remains from cross section of terrace-like surface on left bank of Ema R. (basin of Sukhona R.) at Voskresenskoye, Vologda Oblast, $15 \mathrm{~km} \mathrm{SW}$ of Vologda $\left[59^{\circ} 15^{\prime} \mathrm{N}\right.$ Lat, $39^{\circ} 55^{\prime} \mathrm{E}$ Long. Location relative to Vologda appears improbable; Ema R. is believed to be $\mathbf{S}$ of Vologda; most likely location of site is $59^{\circ} 05^{\prime} \mathrm{N}$ Lat, $40^{\circ} 00^{\prime}$ E Long. (D.B.S.)] Sample coll. 1963 by N. S. Chebotareva and V. B. Sokolova from thinly layered silts and loam with streaks of peaty gyttja, at depth $6 \mathrm{~m}$. Comment: according to pollen data, climatic conditions were cool at time deposits were accumulated, but date is not certain. Deposits could have accumulated either during last Interglacial (beginning or end) or during early interstadials of Valday [Würm] Glaciation. Age is not less than $30,000 \mathrm{yr}$.

\section{Mo-402. Anchakovo, Vologda Oblast}

Peat from Boring No. 2 on [Sukhona-Sheksnya] water divide with absolute alt. up to $161 \mathrm{~m}$, from flat depression of surface at Anchakovo

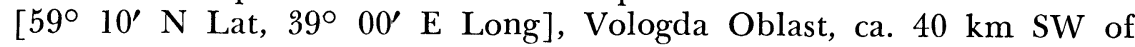
Vologda. Sample coll. 1963 by N. S. Chebotareva and V. B. Sokolova at depth 2.3 to $2.85 \mathrm{~m}$. Accumulation of peat, overlain by sand and boulderless loess-type loams could have occurred during Mikulino [Eem] Interglacial, or during interstadial of Valday [Würm] Glaciation.

\section{Polovetsk-Kupanskoye Bog series, Yaroslavl' Oblast}

Bog [56 $46^{\circ} 45^{\prime} \mathrm{N}$ Lat, $38^{\circ} 25^{\prime} \mathrm{E}$ Long] is in Pereslavl' Raion, Yaroslavl' Oblast. Gyttja accumulated during Valday [Würm] Glaciation. Samples subm. 1964 by N. A. Khotinskiy, Geog. Inst., Acad. of Sci., USSR. Inferred age from pollen data: 13,000 to $14,000 \mathrm{yr}$.

Mo-405.

Gyttja. Depth 8.30 to $8.80 \mathrm{~m}$.

Mo-406.

to $9.4 \mathrm{~m}$.

Gyttja. From same cross section [as Mo-405], but at depth 8.80 
Mo-380. Sogozha River, Yaroslavl' Oblast

Wood from cross section of flood-plain terrace on left bank of Sogozha R. at Teleshovo [58 $48^{\circ} \mathrm{N}$ Lat, $39^{\circ} 15^{\prime} \mathrm{E}$ Long], $60 \mathrm{~km}$ SW of Vologda. Sample coll. 1963 by N. S. Chebotareva and V. B. Sokolova, at depth $4.5 \mathrm{~m}$, from stratum of light-blue clay containing plant remains and wood. This terrace is most extensive in Sogozha R. valley.

\section{Mo-362. Kamennyy Ovrag peat deposit, Vladimir Oblast $>35,000$}

Peat from Kamennyy Ovrag peat deposit $\left[56^{\circ} 22^{\prime} \mathrm{N}\right.$ Lat, $40^{\circ} 22^{\prime} \mathrm{E}$ Long], at Yakimanka village, $20 \mathrm{~km} \mathrm{~N}$ of Vladimir and $8 \mathrm{~km} \mathrm{SE} \mathrm{of}$ Suzdal', Suzdal' Raion, Vladimir Oblast. Deposit lies in layer of lakebog deposits covering depression in surface of Dnepr moraine. Outlet of peat deposit is at base of left slope of Kamennyy Ovrag [Ravine], $1 \mathrm{~km}$ from mouth of ravine [and empties into] Nerl' R. From top to bottom cross section is as follows, thickness indicated:
a. superficial loams, $5 \mathrm{~m}$.
b. light bluish-gray stratified alluvium, $1.2 \mathrm{~m}$.
c. Blackish-brown peat with plant remains, $1.05 \mathrm{~m}$ (sample for $\mathrm{C}^{14}$ analysis was taken from lower $3 \mathrm{rd}$ of stratum).
d. peaty, brownish alluvium, $0.45 \mathrm{~m}$.
e. blackish-green sapropel, $0.45 \mathrm{~m}$.
f. stratified gray alluvium, $0.45 \mathrm{~m}$.
g. fine-grained, water-bearing sand, $0.1 \mathrm{~m}$.

Sample coll. 1963 by S. M. Tseytlin. Inferred age of peat deposit, according to palaeobotanical data: Mikulino [Eem] Interglacial. Comment: age of humus extracted from peat of this ravine is $>45,000 \mathrm{yr}$ (GIN-102a). [Note discrepancies in stratigraphy between Mo-362 and GIN-102a, Geol. Inst. I-III, 1968. (D.B.S.)]

\section{Mo-241. Teysheb-baini fortress, Armenian SSR}

$2640 \pm 100$

Charred wheat from fortress of Teysheb-baini (ancient state of Urartu), $\left[40^{\circ} 11^{\prime} \mathrm{N}\right.$ Lat, $44^{\circ} 35^{\prime} \mathrm{E}$ Long], on Karmir-blur hill, 4 to $5 \mathrm{~km}$ from Erevan. Sample subm. by N. I. Khitarov. Inferred age: 6th century в.c. Comment: date agrees well with previous age determination of scorched wood from identical region: $2600 \pm 135 \mathrm{yr}$ (GIN-1, Geol. Inst. I-III, 1968).

\section{Ancient mines, Armenian SSR}

These samples are connected with development of mining in Armenia.

\section{Mo-356. Agartsin River valley, Armenian SSR [A.D. 620]}

Fragments of charcoal from large accumulation of slag, valley of Agartsin R. in Idzhevan Raion [Idzhevan City, $40^{\circ} 52^{\prime} \mathrm{N}$ Lat, $45^{\circ} 10^{\prime}$ E Long], Armenian SSR. Sample coll. 1962 by S. E. Goginyan at depth $1 \mathrm{~m}$ in slag ca. $2 \mathrm{~m}$ thick. Sample from region of remains of metal- 
lurgical works and ancient settlement, probably center of birthplace of metallurgy [sic]. Objects found at site belong to 5th or 6th millennium B.c.

\section{Mo-357. Gamzachiman, Armenian SSR}

$$
1540 \pm 160
$$

Piece of old pit-prop from ancient mine $30 \mathrm{~m}$ below surface at

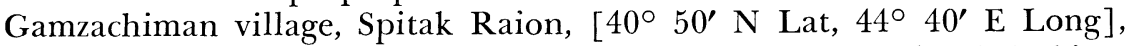
Armenian SSR. Archaeological information about this location is lacking. Mine probably was exploited for gold in 3rd to 6th centuries A.D. Sample coll. 1962 by S. E. Goginyan.

\section{Ayat Peat Deposit series}

Ayat peat bog [ $57^{\circ} 00^{\prime} \mathrm{N}$ Lat, $60^{\circ} 15^{\prime} \mathrm{E}$ Long] (formerly Chernov) is in Nev'yansk Raion, Sverdlovsk Oblast, $30 \mathrm{~km} \mathrm{NW}$ of Sverdlovsk. Samples for $\mathrm{C}^{14}$ and pollen analysis from middle of bog in Pit No. 4, in recent (Neustadt, 1965, p. 124-129) fuscum peat, 5 to $6 \mathrm{~m}$ thick. Subm. 1963 by N. A. Khotinskiy.

Mo-386.

$3510 \pm 90$

Fuscum peat, depth, 1.70 to $1.75 \mathrm{~m}$. Decomposed, $5 \%$.

Mo-388.

$3960 \pm 130$

[2010 B.c.]

Fuscum peat with Eriophorum vaginatum. Depth, 2.55 to $2.60 \mathrm{~m}$. Decomposed, 5 to $10 \%$. Inferred age: 3000 to $4000 \mathrm{yr}$.

Mo-389.

$4630 \pm 150$

[2680 B.c.]

Wood from Boundary Horizon (Neustadt, 1965, p. 70). Depth, 2.65 m. Inferred age: 4000 to $4500 \mathrm{yr}$.

\section{Mo-390.}

$4720 \pm 200$ [2770 B.C. ]

Pine, Eriophorum vaginatum peat from Boundary Horizon (Neustadt, 1965, p. 70), depth, 2.70 to $2.75 \mathrm{~m}$. Decomposed, 30 to $40 \%$. Inferred age: ca. $5000 \mathrm{yr}$.

\section{Mo-394.}

$6230 \pm 150$

Carex peat, depth, 3.45 to $3.50 \mathrm{~m}$. Decomposed, $25 \%$.

\section{Mo-397.}

$9110 \pm 150$

Carex-Hypnum peat, depth, 5.20 to $5.25 \mathrm{~m}$. Decomposed, 20 to $30 \%$. Inferred age: ca. $9000 \mathrm{yr}$.

Mo-398.

$9780 \pm 210$

[7830 B.c.]

Reedy-Hypnum peat with Carex. Depth, 5.40 to $5.45 \mathrm{~m}$. Decomposed, $25 \%$. Inferred age: 9000 to $10,000 \mathrm{yr}$. 
Fossilized wood perforated by teredo molluscs from surface of sea bottom at depth $970 \mathrm{~m}$ in center Denmark Strait, $200 \mathrm{~km} \mathrm{~N}$ of Iceland [67 $55^{\prime} \mathrm{N}$ Lat, $20^{\circ} 15^{\prime} \mathrm{W}$ Long]. Sample coll. 1959 by V. D. Dibner during bottom-charting voyage of research vessel "Sevastopol" " along with gravelly material evidently pertaining to deeply submerged bank.

\section{Mo-415. Hornsund Bay, Vest Spitsbergen}

$810 \pm 70$

Driftwood from marine terrace $38 \mathrm{~m}$ above sea level at Vest Spitsbergen, Treskelen Peninsula [? Torrell Land] on shore of Hornsund Bay $\left[76^{\circ} 58^{\prime} \mathrm{N}\right.$ Lat, $16^{\circ} 20^{\prime}$ E Long]. Coll [n.d.] by D. V. Semevskiy. Comment: driftwood evidently was redeposited by a glacier.

\section{Mo-416. Edgeöya, Spitsbergen}

$5070 \pm 100$

Driftwood from marine terrace $50 \mathrm{~m}$ above sea level from $\mathrm{Edzh}$ Island [Edgeöya], on shore of Blåfjord, [ca. $78^{\circ} 00^{\prime} \mathrm{N}$ Lat, $20^{\circ} 30^{\prime} \mathrm{E}$ Long], S of Cape Pekhuel Lesha [?]. Coll. [n.d.] by V. N. Vasil'yev.

\section{Barentsöya series}

Mo-418. Barentsöya, Spitsbergen

Driftwood from marine terrace $20 \mathrm{~m}$ above sea level Island, Talaver Peninsula [?] [ca $78^{\circ} 30^{\prime} \mathrm{N}$ Lat, $20^{\circ}$ level at Barents [n.d.] by V. N. Vasil'yev.

\section{Mo-419. Barentsöya, Spitsbergen}

Driftwood from cross section of marine terrace $5.5 \mathrm{~m}$ above sea level, at Barents Island, in region of Cape Barkham [78 $18^{\circ} 13^{\prime} \mathrm{N}$ Lat, $20^{\circ} 40^{\prime}$ E Long]. Coll. [n.d.] by B. A. Klubov.

\section{Mo-420. Barentsöya, Spitsbergen}

Driftwood coll. by B. A. Klubov in same place as Mo-419, at elev. $11 \mathrm{~m}$.

\section{Mo-421. Alexandra Land Island, Franz Josef Land A.D. 400}

$1550 \pm 120$

Driftwood from surface of ledge among undisturbed marine deposits. Sample from Franz Josef Land, Alexandra Land Island on shore of Dezhnev Sound $\left[80^{\circ} 45^{\prime} \mathrm{N}\right.$ Lat, $47^{\circ} 00^{\prime} \mathrm{E}$ Long]. Absolute elev.: $5 \mathrm{~m}$. Inferred age: 2500 to 3000 yr. Coll. 1964 by Yu. A. Lavrushin.

\section{India}

\section{Mo-352. Kolar, India}

$$
1460 \pm 160
$$

Carbonaceous material from burned pit prop or bonfire from ancient gold mine at Kolar, India (13 $10^{\circ} \mathrm{N}$ Lat, $78^{\circ} 20^{\prime} \mathrm{E}$ Long), $75 \mathrm{~km}$ 
E of Bangalore, Sample belongs to period of early mining ca. $2000 \mathrm{yr}$ ago. Subm. 1963 by A. I. Tugarinov.

\section{Cuba}

\section{Mo-399. Aguas Gordas, Oriente Province, Cuba [A.D.950]}

$1000 \pm 100$

Charred wood from Aguas Gordas, in Banes municipality, Oriente Prov. (21 $05^{\circ} \mathrm{N}$ Lat, $75^{\circ} 43^{\prime} \mathrm{W}$ Long). [Text gives $20^{\circ} 05^{\prime} \mathrm{N}$, which is not possible, since town of Banes lies almost exactly on 21 st parallel. (D.B.S.)] Ten mounds were uncovered; sample taken from Mound 1 at depth 1.5 to $2 \mathrm{~m}$. Cultural layer was $3.1 \mathrm{~m}$ thick. Tentative age estimation based on thickness of cultural stratum: 500 to $750 \mathrm{yr}$.

Mo-400. El Porvenir, Oriente Province, Cuba

Charred wood from El Porvenir, in Banes municipality, Oriente Province, $11 \mathrm{~km}$ from site of Mo-399 (21 $06^{\prime} \mathrm{N}$ Lat, $75^{\circ} 49^{\prime} \mathrm{W}$ Long). Of 13 mounds discovered, several contained fragments of Spanish pottery, iron objects, and other finds of colonial period (16th century A.D.). Height of mounds less than at Aguas Gordas. Sample from Mound 11 at depth 0 to $0.25 \mathrm{~m}$. Comment: since sample was taken from stratum close to surface, spurious selection is not to be ruled out.

Date lists:

$\begin{array}{ll}\text { Geological Inst. I-III } & \text { Cherdyntsev et al., } 1968 \\ \text { Khlopin Inst. I } & \text { Arslanov, 1968 } \\ \text { Vernadsky Inst. I-IV } & \text { Vinogradov et al., } 1966\end{array}$

Arslanov, Kh. A., 1968, Khlopin Institute radiocarbon dates I: Radiocarbon, v. 10, no. 2 , p. $446-447$.

Arslanov, Kh. A., Gromova, L. I., and Novskiy, V. A., 1966a, A more precise dating for Upper Pleistocene deposits in certain cross sections of the Volga in the Yaroslavl' area with $\mathrm{C}^{14}$, in: Grichuk, V. P., Ivanova, I. K., Kind, N. V., and Ravskiy, E. I., (eds.), Verkhniy pleystotsen. Stratigrafiya i absolyutnaya geokhronologiya (The Upper Pleistocene. Stratigraphy and absolute geochronology): Moscow, Izd. "Nauka," p. 133-140.

Basalikas, A. B., 1957, Basic features of the relief of the Lithuanian SSR: Nauchnye soobshcheniya Instituta geologiyi i geografiyi Akad. Nauk SSR, v. 4, p. 237-246.

Chebotareva, N. S., Serebryannyy, L. P., Devirts, A. L., and Dobkina, E. I., 1962, The absolute age of the lower terraces of the central Russian plain: Izvestiya Akad. Nauk SSR, seriya geograficheskaya, no. 4, p. 70-74.

Cherdyntsev, V. V., Alekseyev, V. A., Kind, N. V., Forova, V. S., and Sulerzhitskiy, L. D., 1968, Radiocarbon dates of the Geological Institute, Academy of Sciences, USSR, I-III: Radiocarbon, v. 10, no. 2, p. 419-445.

Danilans, I. Ya., 1962, Questions of the stratigraphy of the Pleistocene deposits of Latvia: Trudy Instituta geologiyi Akad. Nauk, Latvian SSR, v. 8.

Devirts, A. L., Dobkina, E. I., and Markova, N. G., 1965, The methodology of determining the absolute age of organic specimens by the radiocarbon method, in: Paleogeografiya i khronologiya verkhnego pleystotsena $i$ golotsena po dannym radiouglerodnogo metoda (Upper Pleistocene and Holocene Palaeogeography and chronology according to data of the radiocarbon method): Moscow, Izd. "Nauka," p. $132-138$.

Gimbutas, Marija, 1956, The prehistory of Eastern Europe, Part I: Mesolithic, Neolithic and Copper Age cultures in Russia and the Baltic area: Cambridge, American School of Prehistoric Research, Peabody Museum, Harvard Univ., Bull. no. 20.

Grosval'd, M. G., Devirts, A. L., and Dobkina, E. I., 1961, On the history of the Holocene in Franz Josef Land: Doklady Akad, Nauk SSSR, v. 151, no. 5, p. 1175-1178. 
Grosval'd, M. G., Devirts, A. L., and Dobkina, E. I., 1963, Glacial stages of Sedov and Victoria, in: On the history of "The little ice age" in the Soviet Arctic: Materialy glyatsiol. issledovaniy. Khronikha. Obsuzhdeniya: Moscow, no. 7, p. 149-151. 1964, Another dating for the coasts of Franz Josef Land: Materialy glyatsiol. issledovaniy. Khronikha. Obsuzhdeniya: Moscow, no. 10, p. 273-274.

Khotinskiy, N. A., 1964a, Comparison of schemes for a zonal separation of the Lateand Postglacial periods with the aid of synchronizing levels: Doklady Akad. Nauk. SSSR, v. 156, no. 1, p. 74-75.

$1964 \mathrm{~b}$, Paleogeografiya verkhnego pleystotsena i golotsena vostochnoy okrainy Verkhne-Volzhskoy nizmennosti (The Paleogeography of the Upper Pleistocene and Holocene of the eastern border of the Upper Volga lowland): Abstract of candidate's dissertation, Moscow.

Kondratene, O. P., 1960, Stratigrafiya i paleogeografiya neopleystotsena Litvy po palinologicheskim dannym (The stratigraphy and paleogeography of Lithuania according to palynological data): Abstract of candidate's dissertation, Vilnius.

Neustadt, M. (ed.), 1965, Paleogeografiya i khronologiya verkhnego pleystotsena i golotsena po dannym radiouglerodnogo metoda (Upper Pleistocene and Holocene palaeogeography and chronology in the light of radiocarbon dating), 1965: Moscow, Izd. "Nauka."

Orviku, K. K. and Pirrus, R. O., 1965, Intermoraine deposits of organic origin in Karakyula, Estonian SSR, in: Litologiva i stratigrafiya chetvertichnykh otlozheniy Estoniyi (Lithology and stratigraphy of quaternary deposits in Estonia): Tallin.

Posledniy evropeyskiy lednikovyy pokrov (The last European ice sheet), 1965: Moscow, Izd. "Nauka."

Serebryannyy, L. R., Devirts, A. L., and Markova, N. G., 1962, New data on the absolute age of the Allerød in the environs of Leningrad: Byull. Komissiyi po izucheniyu chetvertichnogo perioda, Akad. Nauk SSSR, no. 27, p. 151-153.

Starik, I. E. and Arslanov, Kh. A., 1961, The $\mathrm{C}^{14}$ age of some samples of the Quaternary period: Doklady Akad. Nauk. SSSR, v. 138, no. 1, p. 102-105.

Tsapenko, M. M. and Makhnach, N. A., 1959, Antropogenovyye otlozheniya Belorussiyi (Anthropocene deposits of Belorussia): Minsk.

Velichko, A. A., Devirts, A. L., Dobkina, E. I., Morozova, T. D., and Chichagova, O. A., 1964, The first determinations of the absolute age of buried soils in loess for the Russian plain: Doklady Akad. Nauk. SSSR, v. 155, no. 3, p. 355-359.

Vinogradov, A. P., Devirts, A. L., Dobkina, E. I., and Markova, N. G., 1962, The determination of absolute age according to $\mathrm{C}^{14}$. Rept. no. 3: Geokhimiya, no. 5, p. $387-402$.

1963, The determination of absolute age according to $\mathrm{C}^{14}$. Rept. no. 4: Geokhimiva, no. 9, p. 795-811.

1966, The determination of absolute age according to $\mathrm{C}^{14}$. Rept. no. 5: Geokhimiya, no. 10, p. 1147-1159.

Vinogradov, A. P., Devirts, A. L., Dobkina, E. I., Markova, N. G., and Martishchenko, L. G., 1956, The determination of absolute age according to $\mathrm{C}^{14}$. Rept. no. 1: Geokhimiya, no. 8, p. 3-9.

1959, The determination of absolute age according to $\mathrm{C}^{14}$. Rept. no. 2: Geokhimiva, no. 8, p. 663-668.

1961, Opredeleniye absolyutnogo vozrasta po $\mathrm{C}^{14}$ pri pomoshchi proportsional'nogo schyotchika (The determination of absolute age according to $\mathrm{C}^{14}$ with the aid of a proportional counter): Moscow, Izd. Akad. Nauk. SSSR.

Vinogradov, A. P., Devirts, A. L., Markova, N. G., and Khotinskiy, N. A., 1963, The determination of the boundaries of the late- and postglacial periods by means of $\mathrm{C}^{14}$ and pollen-analysis data: Geokhimiya, no. 11, p. 971-980.

Zarrina, Ye. P., 1966, A map of the margins of glacial formations and periglacial basins of the northwestern European part of the USSR, in: Grichuk et al., op. cit., p. 28-31. 